\title{
Translational medicine and the human microbiome
}

\author{
Rob Knight \\ From Beyond the Genome: The true gene count, human evolution and disease genomics \\ Boston, MA, USA. 11-13 October 2010
}

We have learned much about the human microbiome, especially with advances in sequencing. However, as with the human genome, translating this knowledge into therapies remains challenging. One key advantage of focusing on the microbiome is that, outside of Star Trek, our genomes change little during our lifetime, yet each of our microbiomes has changed profoundly. Our microbiomes develop from an undifferentiated state that is dependent on delivery mode (i.e. vaginal delivery versus $\mathrm{C}$-section) to the highly distinct communities that populate every crevice of our bodies.

Here I discuss the variation in the human microbiome within and between people, with a focus on the importance of spatially and temporally resolved studies, and the use of animal models, to gain insight into the role of microbes in obesity. Interestingly, many features of the microbiota of humans can be transferred into mice. The prospects for building a translational medicine pipeline, in which a single stool sample can be used to predict which interventions will work for which person, are compelling.

Published: 11 October 2010
Submit your next manuscript to BioMed Central and take full advantage of:

- Convenient online submission

- Thorough peer review

- No space constraints or color figure charges

- Immediate publication on acceptance

- Inclusion in PubMed, CAS, Scopus and Google Scholar

- Research which is freely available for redistribution

Submit your manuscript at www.biomedcentral.com/submit
C Bïomed Central 